\title{
KAJIAN PERANCANGAN ARENA OLAHRAGA ELEKTRONIK
}

\author{
Thea Amelia ${ }^{1)}$, J. M. Joko Priyono Santoso ${ }^{2)}$ \\ 1)Program Studi S1 Arsitektur, Fakultas Teknik, Universitas Tarumanagara, theamelia@yahoo.com \\ 2) Program Studi S1 Arsitektur, Fakultas Teknik, Universitas Tarumanagara, jokop@ft.untar.ac.id
}

\begin{abstract}
Abstrak
Olahraga berkembang ditandai dengan munculnya cabang olahraga baru, salah satunya ialah esports yang juga sedang mengalami perkembangan tiap tahunnya. Kompetisinya pernah diselenggarakan pada Asian Games 2018, namun tempat penyelenggaraannya belum difungsikan secara khusus untuk esports. Oleh karena itu, perancangan esports arena menjadi jawaban dan merupakan bangunan khas milenial yang hadir dan menandai adanya generasi milenial pada zamannya. Kajian literatur dilakukan mengenai generasi milenial, perilaku milenial, nilai kesejamanan (milenial), tipe bangunan, dan esports untuk mengetahui lebih dalam mengenai perancangan esports arena. Metode yang digunakan adalah metode pengumpulan data, primer maupun sekunder, metode deskriptif kuantitatif maupun kualitatif, metode interaksi, metode komparatif, metode analisis dan sintesis, metode grafis, dan metode eksperimental yang dilakukan dengan studi kajian teori, studi matriks, studi ruang gerak, studi karakteristik ruang, studi preseden, studi dan survei tapak, dan studi gubahan massa. Studi tersebut menghasilkan luasan program dan kapasitasnya, rancangan tapak, konsep, bentuk gubahan massa, dan prinsip skematik keruangan (denah). Berdasarkan metode dan studi yang dilakukan, kesimpulannya ialah Esports Arena yang dirancang di Petojo Selatan, Jakarta Pusat, sesuai dengan tema "Dear Millennials, Dialogue Between Type and Behavior" dan program berupa esports arena, ruang latihan esports, plaza dan cafetaria merupakan program yang menjawab hubungan keruangan antara tipe bangunan, perilaku dan kesejamanan milenial, serta perancangan dan konsep bentuk yang memusat, kontras, adanya plaza sebagai ruang tengah, pengalaman ruang penuh teknologi dan menyesuaikan dengan tema cyber menjawab pengaruh dari perilaku dan tantangan kesejamanan milenial.
\end{abstract}

Kata kunci: arena; milenial; olahraga elektronik; perilaku; tipe

\begin{abstract}
Developing sports is characterized by the emergence of new sports, one of them is esports which also developing every year. The competition has been held at the 2018 Asian Games, however the venue has not been used specifically for esports. Therefore, the design of the esports arena is the answer and also the typical building that is present and marks the millennial generation of its time. Literature studies were conducted on millennial generation, behaviour of millennial, millennial era, building types and esports to find out more about the design of the esports arena. The methods used are data collection method, primary and secondary, quantitative and qualitative descriptive method, interaction method, comparative method, analytical and synthesis method, graphical method, experimental method conducted with theoritical studies, matrix studies, space studies, space characteristics studies, precedent studies, site studies and surveys, and mass compositions studies. The study resulted program area and capacity, site design, concepts, forms of mass composition, and schematic spatial principles (floor plan). Based on the methods and studies conducted, the conclusion is esports arena designed, in accordance with the theme "Dear Millennials, Dialogue between Type and Behavior" and programs in the form of esports arena, esports training rooms, plaza and cafeteria are programs that address spatial relationships between building types, millennial behavior and millenial era, as well as the design and concept of a centralized form, contrast, the existence of a plaza as a central space, technology space experience, and adaptive to the cyber theme responds to the influence of millennial behaviors and challenges.
\end{abstract}

Keywords: arena; behavior; esports; millennial; type 


\section{PENDAHULUAN}

Olahraga merupakan kegiatan yang digemari oleh banyak orang, dan dapat berupa kegiatan fisik (sepak bola, basket) karena melibatkan pengerahan tenaga fisik dan keterampilan; dan kegiatan non fisik (catur, bridge) karena menggunakan kemampuan otak dan pengaturan strategi untuk bersaing. Olahraga berkembang terlihat dengan munculnya cabang-cabang olahraga baru karena perkembangan budaya dan waktu. Kini, esports menjadi salah satu cabang olahraga baru yang diminati oleh generasi milenial (Newzoo, 2017). Dalam permainannya, esports menggunakan pengaturan strategi, kecepatan berpikir dan kecepatan mengendalikan perangkat.

Esports sedang mengalami perkembangan tiap tahunnya ditandai dari kenaikan jumlah pemain, jumlah hadiah dan monetisi esports yang ketiganya terus meningkat tiap tahunnya (Sachs, 2018). Seperti olahraga lainnya, terdapat kompetisi esports, diantaranya diselenggarakan sebagai salah satu cabang olahraga di Asian Games 2018. Namun, tempat penyelenggaraan kompetisi tersebut belum ada yang difungsikan secara khusus untuk esports, dan harus tersedia mengingat perkembangannya yang meningkat dan minat yang tinggi.

Oleh karena itu, perancangan esports arena dapat menjadi jawaban untuk kebutuhannya yang belum terwadahi. Esports arena dapat menjadi wadah akan minat esports yang tinggi dan pemicu berlangsungnya efek domino untuk perkembangan lainnya. Esports arena menjadi tempat penyelenggaraan kompetisi esports dan program untuk esports secara khusus. Esports arena inilah bangunan khas yang hadir dan menandai bahwa pernah ada generasi milenial pada zamannya.

Untuk mempermudah penulisan ini, penulis menggunakan rumusan-rumusan masalah, yaitu mengenai bagaimana program yang menjawab hubungan keruangan antara tipe bangunan, perilaku dan kesejamanan milenial dan mengenai bagaimana perancangan dan konsep bentuk esports arena di lokasi tapak terpilih akibat pengaruh dari perilaku milenial dan tantangan kesejamanan milenial.

Visi dari perancangan esports arena adalah menjadikan esports mampu bersaing dengan olahraga lainnya secara global dengan standar dan teknologi yang tinggi. Sedangkan misinya yaitu menghasilkan pemain profesional untuk mewujudkan Indonesia menjadi negara yang berprestasi dan disegani di dunia di bidang esports, pemicu untuk perkembangan komunitas dan industri di bidang esports di Indonesia, mewadahi penyelenggaraan kompetisi maupun kegiatan pelatihan di bidang esports, dan menjadi titik kumpul pemain maupun komunitas di bidang esports.

\section{KAJIAN LITERATUR}

Kajian literatur dilakukan mengenai generasi milenial, perilaku milenial, nilai kesejamanan (milenial), tipe bangunan, dan esports untuk mengetahui lebih dalam mengenai perancangan esports arena.

\section{Generasi Milenial}

Saat ini ada empat kelompok besar dalam demografi, yaitu Baby Boomer (lahir tahun 19461964), Gen-X (lahir tahun 1965-1980), Millennial (lahir pada 1981-2000), dan Gen-Z (lahir pada 2001-sekarang) (Walidah, 2017: 320). Generasi milenial memiliki populasi terbesar yaitu 85.531 .500 orang (32\%) pada tahun 2019 (Katadata, 2019).

\section{Perilaku Milenial}

Menurut Kamus Besar Bahasa Indonesia (2019), perilaku adalah tanggapan atau reaksi individu terhadap rangsangan atau lingkungan. Generasi milenial lahir ketika teknologi mulai muncul dan berkembang (Panindya, 2018). Penggunaan teknologi itu melalui pemakaian gadget. Menurut Merriam-Webster (2019), gadget digunakan untuk berbagai macam kebutuhan salah satunya ialah penggunaan internet. 
Menurut Asosiasi Penyelenggara Jasa Internet Indonesia (APJII), pengguna internet di Indonesia mencapai 143.26 juta jiwa atau $54.68 \%$ dari total populasi dan angka tersebut tersebut meningkat. Newzoo memperkirakan sekitar 42.8 juta orang yang terkoneksi internet di antaranya ialah gamers. Jumlah yang besar tersebut menunjukkan adanya potensi besar di industri game Indonesia. Sebesar 56\% gamers mau dan mampu membayar untuk membeli produk di dalam game (Newzoo, 2015).

Secara total, penghasilan yang didapatkan dari industri game Indonesia ini diperkirakan mencapai 2.5 triliun rupiah di tahun 2014, dan terus meningkat. Angka ini menempatkan Indonesia menjadi negara dengan pendapatan industri game terbesar di Asia Tenggara dan pendapatan industri ke-17 terbesar di dunia (Setiawan, 2017).

Berdasarkan Newzoo tahun 2017, mayoritas gamers ialah generasi milenial yaitu berusia 21-35 tahun. Ini berarti perkembangan esports terjadi karena generasi milenial. Selain itu, minat akan esports juga digemari oleh generasi $Z$, atau generasi penerusnya.

\section{Nilai Kesejamanan (Milenial)}

Menurut Kamus Besar Bahasa Indonesia (2019), nilai adalah sifat-sifat (hal-hal) yang penting atau berguna bagi kemanusiaan. Kesejamanan berasal dari bahasa Inggris yaitu 'contemporaneity', yang berarti kualitas atau keadaan menjadi kontemporer (MerriamWebster, 2019). Oleh karena itu, nilai kesejamanan ialah hal yang penting atau berguna bagi manusia pada masa kini. Nilai kesejamanan itu diantaranya ialah perkembangan esports.

Menurut survei Goldman Sachs, terdapat beberapa parameter terkait pertumbuhan esports pada masa kini, yaitu peningkatan jumlah penonton esports, kenaikan jumlah hadiah dalam setiap turnamen, dan monetisasi esports. Ketiga parameter tersebut meningkat dari tahun ke tahun, dan mengungguli olahraga tradisional (basket, baseball, dan sebagainya) (Sachs, 2018). Oleh karena itu, adanya esports ialah hal yang penting dan berguna yang terjadi pada masa generasi milenial, serta membawa perubahan berkelanjutan.

\section{Tipe Bangunan}

Menurut Kamus Besar Bahasa Indonesia (2019), tipe adalah model; contoh; corak. Bangunan adalah struktur biasanya beratap dan berdinding dibangun untuk penggunaan permanen (seperti untuk tempat tinggal) (Merriam-Webster, 2019). Tipe Bangunan adalah model/ contoh/ corak struktur yang biasanya beratap dan berdinding dan dibangun untuk penggunaan permanen.

Tipe bangunan yang sesuai dengan isu perilaku dan kesejamanan milenial ialah bangunan yang mewadahi pelaku gamers, yaitu esports arena sebagai sarana rekreasi dan pertunjukan, yang merupakan perkembangan tipe bangunan olahraga pada umumnya. Tanpa generasi milenial, esports tidak akan berkembang sedemikian rupa. Bangunan esports ini juga menjadi bangunan khas yang hadir dan menandai bahwa pernah ada generasi milenial pada zamannya.

Dalam merancang esports, terdapat perbedaan penonton esports dengan penonton olahraga tradisional. Dalam pertandingan sepak bola atau NBA, penonton ingin berada pada kursi terdepan atau sedekat mungkin dengan lapangan. Namun, penonton esports akan duduk lebih jauh ke belakang, bahkan di tingkat tempat duduk atas. Di sana mereka memiliki garis pandang yang lebih baik ke layar.

Pada olahraga tradisional, fasilitas pendukung hanya berupa concessions dan toilet, sedangkan pada esports, karena sifat dan lamanya acara yang dapat berlangsung hingga delapan atau sembilan jam, ada banyak periode waktu ketika penonton ingin bersosialisasi, bermigrasi dan berkumpul di area pinggiran, keinginan untuk terlibat dalam hal-hal menyenangkan seperti cosplay, bertemu dengan karakter, mengambil bagian dalam pengalaman siaran, bertemu-sapa dengan tim, dan sebagainya.

Pengalaman teknologi menjadi hal yang penting bagi keberhasilan esports. Karakteristik penonton generasi milenial yang digital native, membuat adanya kemungkinan retail, menu 
makanan dan minuman, dapat dipilih oleh penonton melalui perangkat seluler, perlunya kemudahan untuk mengakses segala macam hal untuk menyesuaikan pengalaman esports, dan adanya akses penonton ke tim dan akses pesaing untuk bertemu dan menyapa melalui chat, serta perlunya pengalaman Augmented Reality (AR) untuk penonton ketika kompetisi berlangsung melalui perangkat seluler. Perangkat tersebut melengkapi berlangsungnya acara dan memadukan pengalaman virtual dan nyata (Merlin, 2018).

\section{E-Sports}

'Esports' merupakan singkatan dari electronic sports yang berasal dari bahasa Inggris dan jika diterjemahkan ke dalam Bahasa Indonesia, memiliki arti olahraga elektronik. Menurut English Oxford Living Dictionaries, esport adalah permainan video multipemain yang dimainkan secara kompetitif untuk penonton, biasanya oleh gamer profesional. Jenis kegiatan permainan esports terbagi menjadi dua, yaitu esports fisik dan esports non fisik.

Permainan esports fisik ialah permainan dengan menggunakan sensor pada perangkat game, dimana pemain menggerakkan gerakan fisik pada dunia nyata yang akan terkoneksi dengan dunia maya, sehingga gerakan yang dihasilkan pada dunia nyata dan maya serupa.

Contoh permainan esports fisik seperti permainan olahraga voli, baseball (Gambar 1), tennis, archery, yoga, fitness, dan sebagainya. Perangkat game yang digunakan diantaranya seperti kinect sports xbox, wii, vr (virtual reality), dan sebagainya.

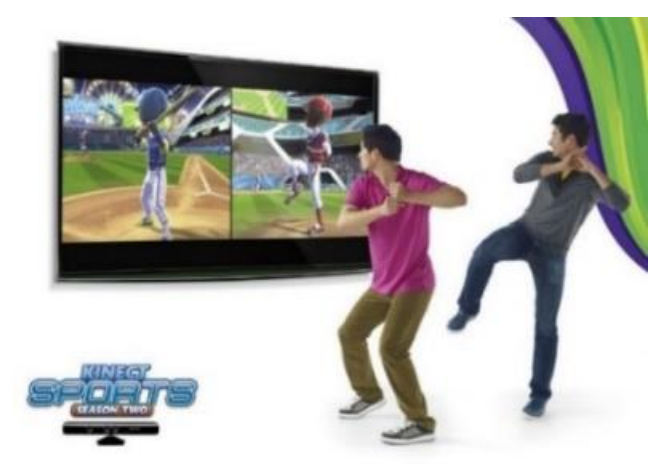

Gambar 1. Permainan esports fisik baseball

Sumber : https://static.giantbomb.com/uploads/original/8/85733/2010818-2010710kinect_sports_season_two_baseball2.jpg

Permainan esports non fisik ialah permainan dengan menggunakan game melalui perangkat komputer, dimana pemain menggunakan ketangkasan non fisik seperti mengatur strategi, kecepatan berpikir, dan kecepatan mengendalikan mouse dan keyboard dalam menggerakan tokoh di dalam game (Bramantya, 2019).

Contoh permainan esports non fisik diantaranya ialah Counter Strike, DOTA, Mobile Legend, PUBG, dan sebagainya. Perangkat game yang digunakan diantaranya seperti PC (Personal Computer) (Gambar 2), laptop, dan sebagainya.

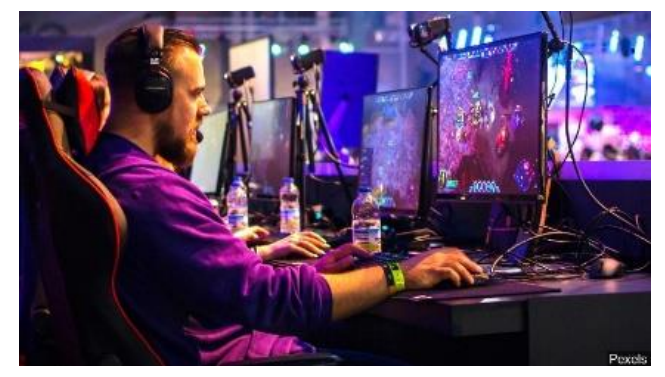

Gambar 2. Permainan esports non fisik Sumber : https://media.graytvinc.com/images/810*455/1280x720_80829P00-FCDUO.jpg 


\section{METODE}

Metode yang digunakan metode pengumpulan data, primer maupun sekunder, metode deskriptif kuantitatif maupun kualitatif,metode interaksi, metode komparatif, metode analisis dan sintesis, metode grafis, dan metode eksperimental yang dilakukan dengan studi kajian teori, studi matriks, studi ruang gerak, studi karakteristik ruang, studi preseden, studi dan survei tapak, dan studi gubahan massa. Sedangkan analisis dan sintesis yang dilakukan ialah analisis program ruang, analisis lokasi dan tapak, dan analisis konsep dan bentuk rancangan.

\section{Metode Pengumpulan Data}

Metode pengumpulan data primer (survei, atau secara langsung) dan data sekunder (buku, ebook, dan sebagainya) merupakan kajian teori, yaitu mencari lebih dalam mengenai generasi milenial, perilaku milenial, nilai kesejamanan (milenial), tipe bangunan, esports melalui data sekunder (buku, ebook, dan sebagainya). Metode ini dilakukan untuk memahami tema "Dear Millennials, Dialogue Between Type and Behavior", sehingga menghasilkan latar belakang yang kuat untuk proyek esports arena yang dirancang. Selain itu, metode ini juga digunakan untuk memahami lebih dalam mengenai teori pattern language yang digunakan sebagai pendekatan perancangan.

Metode pengumpulan data berupa studi ruang gerak dilakukan dengan mencari standar ruang gerak dari literature (data sekunder) atau membuat standar ruang gerak sendiri sesuai kebutuhan. Studi ruang gerak menghasilkan luasan, kapasitas dan volume ruang.

Metode pengumpulan data berupa studi karakteristik ruang dilakukan dengan mencari karakteristik ruang yang dibutuhkan dari literature (data sekunder), yaitu perbedaan esports dengan olahraga tradisional. Studi ini menghasilkan syarat ruang dan ketentuan khusus suatu ruang.

Metode pengumpulan data berupa data primer dilakukan melalui survei secara langsung pada tapak, dan menghasilkan pengetahuan mengenai tapak dan sekitarnya, sirkulasi pada sekitar tapak, dan pengukuran suara dalam desibel.

\section{Metode Deskriptif}

Metode deskriptif dilakukan dengan menjelaskan secara lisan dan detail keseluruhan jurnal, baik pada pendahuluan, kajian teori, metode, diskusi dan hasil. Metode deksriptif dapat dibagi menjadi deskriptif kuantitatif (angka, penghitungan) dan deskriptif kualitatif (kualitas). Metode deskriptif kuantitatif dilakukan untuk penghitungan kapasitas, luasan program, dan luas tapak. Sedangkan metode deskriptif kualitatif dilakukaan untuk menjelaskan hampir keseluruhan jurnal, misalnya analisis dan sintesis.

\section{Metode Interaksi}

Metode interaksi berupa studi matriks dilakukan dengan melihat hubungan antara variabel A, B, C, dan seterusnya sesuai kebutuhan. Pada studi yang dilakukan, variablenya berupa keterkaitan dan perubahan antara beberapa aspek yaitu nilai kesejamanan milenial, perilaku milenial dengan generasi $X, Y$, dan Z. Studi matriks menghasilkan beberapa faktor yang mempengaruhi proyek terpilih, tambahan latar belakang proyek terpilih, dan program untuk proyek terpilih.

\section{Metode Komparatif}

Metode komparatif dilakukan pada studi preseden, yaitu dengan komparasi bangunan preseden, seperti lokasi, kapasitas bangunan, fasilitas yang disediakan, kapasitas fasilitas yang diperlukan, fungsi pendukung, keunggulan bangunan preseden, skala administrasi bangunan, sistem transportasi, fasilitas dalam radius $1 \mathrm{~km}$, eksterior dan interior. Studi ini menghasilkan kriteria pemilihan tapak, program dan luasannya, kapasitas bangunan dan fasilitas yang diperlukan, skala administratif bangunan, dan bentuk massa. 


\section{Metode Analisis dan Sintesis}

Metode analisis dan sintesis dilakukan dengan menganalisis program ruang, analisis lokasi dan tapak, dan analisis konsep dan bentuk rancangan. Analisis program ruang dilakukan dengan menganalisis target pengguna, kebutuhan ruang berdasarkan pelaku dan kegiatannya, hubungan ruang berdasarkan sirkulasi pengguna bangunan, karakter ruang fasilitas, penetapan kapasitas, dan besaran ruang. Analisis lokasi dan tapak dilakukan dengan menentukan kriteria pemilihan tapak, alternatif lokasi, alternatif tapak, analisis kota, kawasan, dan tapak (makro, meso, dan mikro), serta analisis S.W.O.T (Strenght, Weakness, Opportunity, Threat). Analisis Konsep dan bentuk rancangan dilakukan dengan membuat design scheme, tema, konsep dan mengaplikasikannya pada bangunan.

Metode analisis dan sintesis berupa studi dan survei tapak dilakukan dengan mencari alternatif lokasi, dan alternatif tapak, untuk kemudian dilakukan penilaian/ scoring untuk mendapatkan tapak yang memiliki poin tertinggi sebagai tapak dari proyek. Survei tapak juga dilakukan sebagai data primer dalam penentuan lokasi tapak. Studi dan survei tapak ini menghasilkan analisis sirkulasi, orientasi, kebisingan, keadaan sekitar tapak, dan rancangan tapak.

Metode analisis dan sintesis berupa studi gubahan massa dilakukan dengan memprakirakan gubahan massa terbaik dengan eksperimental bentuk. Studi ini kemudian dilanjutkan dengan design scheme untuk menghasilkan bentuk gubahan massa akhir dan konsepnya.

\section{Metode Grafis}

Metode grafis dilakukan dengan menuangkan ide perancangan melalui gambar grafis, yaitu seperti gambar perspektif, diagram dan grafis analisis lokasi, diagram dan grafis analisis kota, kawasan, dan tapak, grafis tema konsep ide dan design scheme, diagram dan exploded mengenai programmatic, gambar kerja (blok plan, site plan, denah, tampak dan potongan), potongan perspektif, exploded denah, perspektif eksterior dan interior, axonometri struktur, mekanikal elektrikal dan plumbing, detail gambar kerja, dan material keseluruhan bangunan dalam bentuk grafis. Dengan metode ini ide yang dituangkan dan perancangan menjadi mudah dibaca dan dipahami.

\section{Metode Eksperimental}

Metode eksperimental dilakukan dengan melakukan eksperimen atau percobaan berulang kali mengenai bentuk gubahan massa dengan mempertimbangkan kesesuaian dengan fungsi, analisis sirkulasi, orientasi dan kebisingan, estetika, kesesuaian dengan tema dan konsep sehingga mendapatkan bentuk yang dianggap terbaik. Selain itu, metode eksperimental juga dilakukan untuk mendapatkan tema dan konsep dengan mempertimbangkan kesesuaian dengan proyek yang dirancang.

\section{DISKUSI DAN HASIL}

\section{Program Ruang}

Dalam menentukan program ruang, diawali dengan mengetahui target dari penggunanya, yaitu diutamakan untuk generasi milenial, dan juga semua umur yang memiliki ketertarikan di bidang esports. Kemudian melakukan analisis kebutuhan ruang yang dilakukan dengan memahami kegiatan yang dilakukan masing-masing pelaku dan menemukan ruang yang dibutuhkan. Hasil analisis kebutuhan ruang menghasilkan rencana program ruang. Kemudian melakukan pemetaan hubungan ruang yang ada, berdasarkan masing-masing alur sirkulasi pengguna bangunan.

Berdasarkan kajian teori dan studi karakter ruang, esports arena membutuhkan suasana ruang yang berbeda dengan olahraga tradisional. Karakter ruang fasilitas menghasilkan syarat setiap ruang berupa elemen dan perabot yang harus dipenuhi untuk menciptakan suasana ruang dan memenuhi tujuan. 
Penetapan kapasitas latihan esports non fisik dilakukan dengan menganalisis dan komparasi dari studi preseden, begitu juga untuk penetapan kapasitas esports arena, yang dilakukan dengan analisis dan komparasi studi preseden serta dari studi literatur. Dari proses tersebut menghasilkan program ruang dengan standar ruang dan sumbernya, kapasitas, jumlah unit, dan luas tiap ruang.

Program ruang terbagi menjadi 4 program besar yaitu esports arena, latihan esports, publik, pengelola \& service. Esports arena menjadi program utama, sedangkan fasilitas pendukugnya ialah latihan esports, ruang publik seperti plaza dan cafetaria. Esports arena memiliki luas $2263.7 \mathrm{~m} 2$ dengan persentase sebesar 46.3\%, latihan esports memiliki luas 741 $\mathrm{m} 2$ dengan persentase sebesar $15.2 \%$, publik memiliki luas $1609.5 \mathrm{~m} 2$ dengan persentase sebesar 33\%, pengelola \& service memiliki luas $267.4 \mathrm{~m} 2$ dengan persentase sebesar $5.5 \%$, dan keseluruhan luas total ialah $5346.3 \mathrm{~m} 2$. Jika ditambah luas basement untuk parkir dan service maka total keseluruhan luasnya ialah $8989.1 \mathrm{~m} 2$.

Pada program ruang, kapasitas didapat dari standar, analisis penetapan kapasitas, dan menyesuaiakan kebutuhan. Standar program ruang didapat dari Neufert Data Arsitek, Standar Perencanaan Teknik Stadion - Menpora, studi preseden, studi ruang gerak, dan asumsi.

\section{Lokasi dan Tapak}

Sebelum menentukan lokasi, perlu mengetahui kriteria pemilihan tapak yang didapat dari studi preseden, yaitu membutuhkan lokasi yang mudah diakses dengan transportasi umum, berada dekat dengan fasilitas pendidikan, titik kumpul komunitas generasi milenial, dan titik kumpul komunitas esports. Selain itu, esports arena yang dirancang juga difungsikan menjadi pemicu untuk pembangunan bangunan esports lainnya, sehingga lokasi di Jakarta yang merupakan penduduk terbesar, tepatnya di Jakarta Pusat menjadi tempat yang memudahkan pengunjung datang dari berbagai daerah dan strategis untuk menjadi awal pemicu pembangunan esports lainnya.

Lokasi ditentukan di Jakarta Pusat, dan berada dekat dengan Jakarta Barat yang merupakan daerah universitas dan juga ditentukan berdasarkan letak titik kumpul generasi milenial, penentuan didasarkan dari mapping kota Jakarta, yaitu mapping transportasi umum dan mapping universitas dan titik kumpul generasi milenial. Dari komparasi, analisis dari alternatif lokasi, dipilih lokasi yang berada di perbatasan Jakarta Barat, yaitu kecamatan Tanah Abang dan Kecamatan Gambir, karena keduanya memenuhi kriteria pemilihan lokasi.

Beberapa kriteria pemilihan alternatif tapak yang dipilih ialah berada di Kecamatan Tanah Abang atau Kecamatan Gambir, berada di tanah kosong atau bangunan yang layak dibongkar, dan memiliki total luas bangunan lebih dari $8989.1 \mathrm{~m} 2$. Dari alternatif tapak yang terpilih, dilakukan penilaian dengan beberapa kriteria dan value dari setiap kriteria tersebut. Maka, tapak yang terpilih ialah tapak yang berada di Jalan Abdul Muis, Gambir, Jakarta Pusat, yang memiliki nilai tertinggi. Tapak memiliki luas 5252 m2, KDB 60\%, KLB 2.40, KB 4, KDH 30\%, KTB 55\%, Tipe D (deret), dan PSL P (padat).

Setelah menemukan tapak terpilih, kemudian menganalisis kawasan (meso), seperti infrastruktur (jalanan), area biru, halaman, area hijau, solid void, zoning, hirarki jalan, kepadatan penduduk, dan ketinggian bangunan. Analisis kawasan menghasilkan keadaan kawasan sekitar, perubahan kawasan sekitar, akses menuju tapak, perlunya dekat dengan titik transportasi, perlunya penyesuaian skyline, perlunya penyesuaian dengan orientasi bangunan sekitar, perlunya ruang terbuka, titik transportasi di sekitar tapak, dan mengetahui potensi perkembangan tapak. 


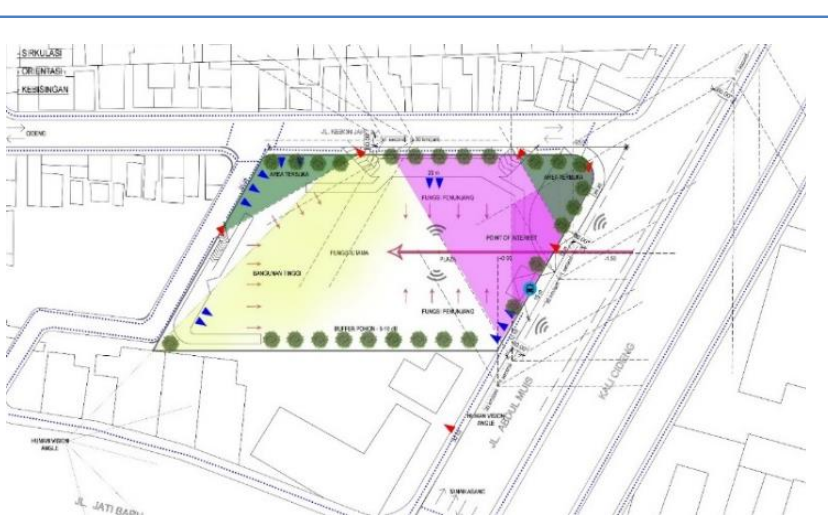

Gambar 3. Analisis sirkulasi, orientasi, dan kebisingan tapak Sumber: Penulis, 2019

Analisis tapak (gambar 3) yang dilakukan berupa analisis sirkulasi, analisis orientasi dan kebisingan tapak. Dari ketiga analisis tersebut didapat titik entrance masuk kendaraan maupun pedestrian, orientasi bangunan yang menghadap ke jalan utama dan ruang tengah (plaza), penggunaan pohon sebagai buffer, meninggikan peil lantai, dan penggunaan material peredam.

Analisis S.W.O.T dilakukan untuk memanfaatkan Strenght dan Opportunity, dan mencari solusi untuk Weakness dan threat, sehingga didapat beberapa strategi yaitu pembangunan esports arena di lokasi yang strategis dan sesuai dengan target pengguna, menjadikan titik kumpul untuk komunitas esports, mengutamakan pengguna transportasi umum dengan membuat shelter di bagian depan, mengutamakan pedestrian dengan menjadikan lantai dasar sebagai ruang publik, menciptakan program yang positif seperti esports fisik dan kompetisi yang sehat, merancang sirkulasi di dalam site secara efektif dan efisien, merancang fasad depan yang menarik, dan merancang sirkulasi ke dalam site yang efektif dan efisien.

\section{Konsep dan Bentuk Rancangan}

Tema dari bangunan yang dipilih ialah cyber, yaitu suatu yang berhubungan dengan budaya komputer, teknologi informasi, dan virtual reality. Dari tema tersebut maka konsep dari bangunan ini ialah transisi dari reality menuju virtual reality, sehingga setiap pengunjung yang masuk ke dalam tapak akan mengalami pengalaman ruang yang berbeda dan kontras dari biasanya. Suasana ruang yang berbeda dibuat dengan desain plaza dan interior yang menyesuaikan dengan tema cyber yaitu berbentuk jaringan-jaringan komputer, selain itu juga dengan lampu-lampu neon dan screen di seluruh bangunan, sehingga menarik pengunjung untuk masuk ke dalam tapak. Bentuk massa juga memiliki konsep untuk memaksimalkan fungsi esports arena, dengan mengambil bentuk stage arena yang memiliki tingkat efektivitas tertinggi terutama berbentuk lingkaran, sehingga dapat menampung pengunjung dengan jumlah yang banyak. Kemudian untuk sirkulasi dalam bangunan utama dibuat memutar dan terdapat 2 sirkulasi untuk memecah jumlah pengunjung yang datang. Bentuk bangunan juga dibuat terbuka dan kontras dari sekitarnya untuk mengundang pengunjung datang dan pengunjung dapat merasakan perubahan suasana ruang. Maka dari itu, bentuk bangunan utama berbentuk lingkaran, menyesuaikan dengan efektivitas jumlah pengunjung, dan orientasi seluruh bangunan menuju ke plaza.

Selain itu, pendekatan perancangan yang digunakan adalah pattern languange, karena mudah dan dapat diaplikasikan pada perancangan esports arena. Pattern language adalah metode yang mempunyai struktur jaringan, dalam menggunakannya perlu berurutan dari pola yang besar ke pola yang lebih kecil.

- Meletakkan 'magic of city' dalam jangkauan semua orang di kota metropolitan (the magic of city) -> esports arena dapat menjadi sesuatu yang berbeda/ 'magic of city', sehingga letak esports arena berada di Jakarta Pusat mudah dijangkau. 
- Membuat sistem jalur sepeda dan menyediakan rak sepeda dekat pintu masuk utama tiap bangunan. (bike paths and racks) -> tapak esports arena yang mengutamakan pedestrian dan pengguna sepeda sehingga menyediakan jalur dan rak sepeda di entrance

- Di setiap lingkungan kerja dan komunitas, membuat sebidang ruang untuk publik, sebagian tempat tertutup, dengan beberapa atap, kolom, tanpa dinding, atau mungkin dengan teralis. Meletakkan di samping jalan yang penting dan dapat dipandang oleh banyak orang. (public outdoor room) -> esports arena merupakan tempat komunitas, sehingga membutuhkan ruang publik yang tertutup maupun terbuka seperti plaza, letak plaza juga berada di pinggir jalan yang dapat mudah dipandang banyak orang agar dapat menarik pengunjung.

- Mengatur bangunan sehingga membentuk pedestrian dengan banyak pintu masuk dan tangga terbuka, sehingga akses jalan berada di outdoor, bukan di dalam bangunan. (pedestrian street) -> menyesuaikan dengan jumlah pengunjung yang banyak dan pedestrian serta sistem transportasi yang diutamakan pada tapak sehingga entrance dibuat lebih dari satu dan adanya arcades.

- Membuat semua ruang luar yang mengelilingi bangunan positif. Setiap ruang dikelilingi dengan pohon, pagar, arcade, dan tempat berjalan, sehingga menjadi ruang luar yang positif (positive outdoor space) (Gambar 4)-> diaplikasi dengan plaza yang terbuka lebar karena kurangnya vegetasi pada kawasan, dan adanya pohon dan plaza dapat menjadi tempat berkumpul sekaligus buffer dari bising dan debu jalanan.

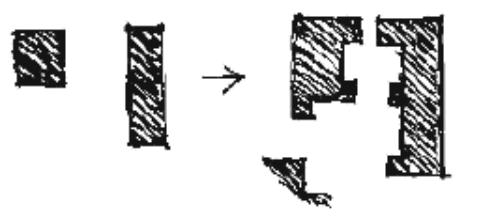

Transform this. . . . to this.

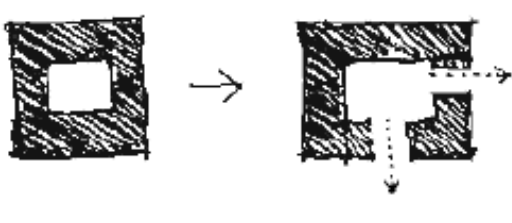

Transform this. .... to this.

Gambar 4. Positive outdoor space

Sumber : Alexander, 1997

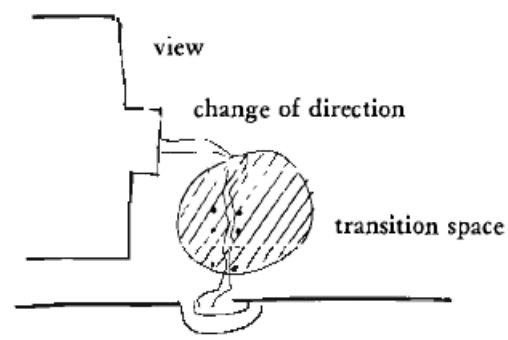

Gambar 5. Entrance Transition

Sumber : Alexander, 1997

- Buat ruang transisi antara jalan dan depan pintu, seperti perubahan cahaya, suara, arah, permukaan, level, dan perubahan tampilan. (entrance transition) (Gambar 5) -> menyesuaikan dengan konsep transisi dunia nyata ke maya melalui perubahan pengalaman ruang esports dan teknologi ketika memasuki tapak.

- Di mana pun jalur berjalan di sepanjang tepi bangunan, bangunlah dan gunakan arcade. (arcades) $\rightarrow$ mengutamakan pedestrian dan pengguna transportasi umum sehingga menyediakan arcades.

- Kelilingi tempat-tempat pertemuan umum dengan kantong aktivitas kecil, yang menjorok ke depan ruang terbuka dan berisi kegiatan yang membuat orang untuk berhenti dan terlibat. (activity pockets) (Gambar 6) -> esports arena merupakan tempat komunitas sehingga perlunya menyediakan activity pockets pada plaza. 
- $\quad$ Pada tengah ruang terbuka membuat sesuatu yang memberikan denyut nadi yang kuat sehingga menarik orang ke tengah. (something roughly in the middle) -> terdapat ruang tengah tengah sehingga perlu menyediakan hologram \& screen pada tengah plaza dan esports arena.

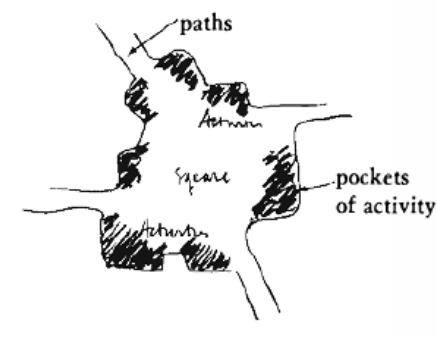

Gambar 6. Activity pockets

Sumber: Alexander, 1997

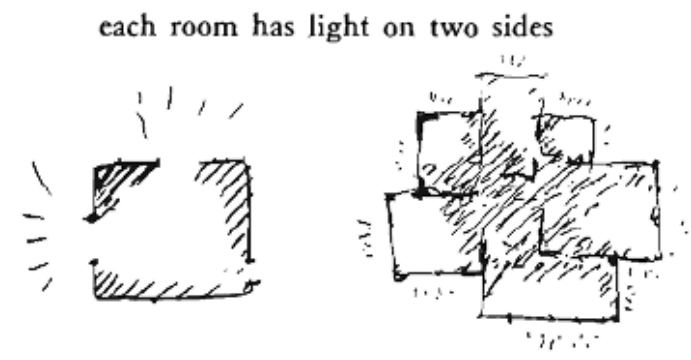

Gambar 7. Light on Two Sides of Every Room Sumber: Alexander, 1997

- $\quad$ Beri setiap lembaga dan kelompok sosial tempat di mana orang bisa makan bersama. (communal eating) -> esports arena merupakan titik kumpul sosial dan komunitas sehingga memerlukan program cafeteria untuk berkumpul bersama.

- Membuat setiap ruang memiliki sisi ruang luar setidaknya pada dua sisi, dan tempatkan jendela. (light on two sides of every room) (Gambar 7) -> Indonesia dengan iklim tropis sehingga memerlukan perputaran udara dengan jendela pada 2 sisi setiap ruang.

- $\quad$ Menjadikan tempat yang cerah sebagai ruang luar yang penting terlindung dari angin. (sunny place) -> adanya ruang terngah sebagai titik kumpul yaitu plaza yang terlindung dari angina.

- Membuat ruang publik yang terbuka lebar ke jalan. (opening to the street) -> esports arena sebagai ruang public maka orientasinya seperti plaza perlu terbuka ke jalan utama (Alexander et al, 1977).

Berikut merupakan gambar perancangan dan gambar kerja dari esports arena.

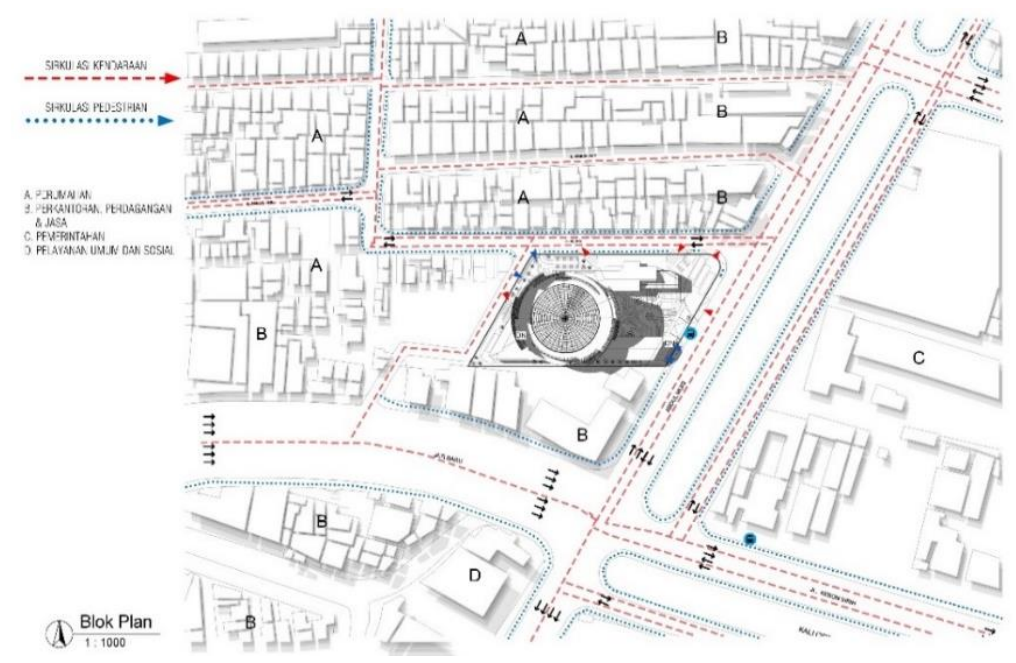

Gambar 8. Blok Plan

Sumber: Penulis, 2019

Blok plan (Gambar 8) dibuat untuk mengetahui akses kendaraan dan pedestrian menuju tapak, serta bangunan sekitar. Dari blok plan diketahui kemudahan akses menuju tapak, entrance tapak lebih dari satu, dan bentuk bangunan yang kontras dengan sekitarnya menyesuaikan dengan tema. 


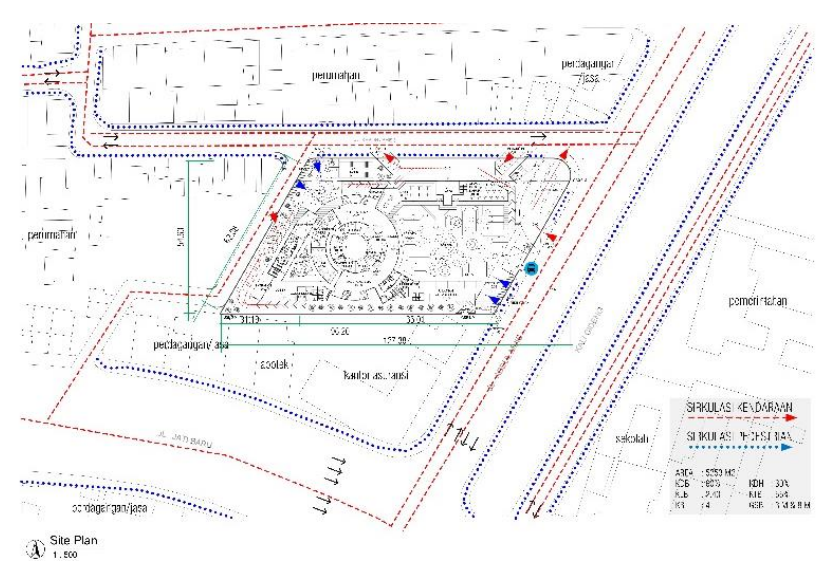

Gambar 9. Site Plan

Sumber: Penulis, 2019

Site plan (Gambar 9) untuk mengetahui akses ke dalam tapak, akses di dalam tapak kendaraan maupun pedestrian, ketentuan KDB, KLB, KDH, KB, luas tapak, dan ukuran tapak. Pada site plan, akses tranportasi umum lebih diutamakan, begitu juga akses untuk pedestrian yang cukup mudah. Sedangkan untuk akses kendaraan pribadi lebih dikesampingkan, namun tetap tersedia, tidak terjadi cross.

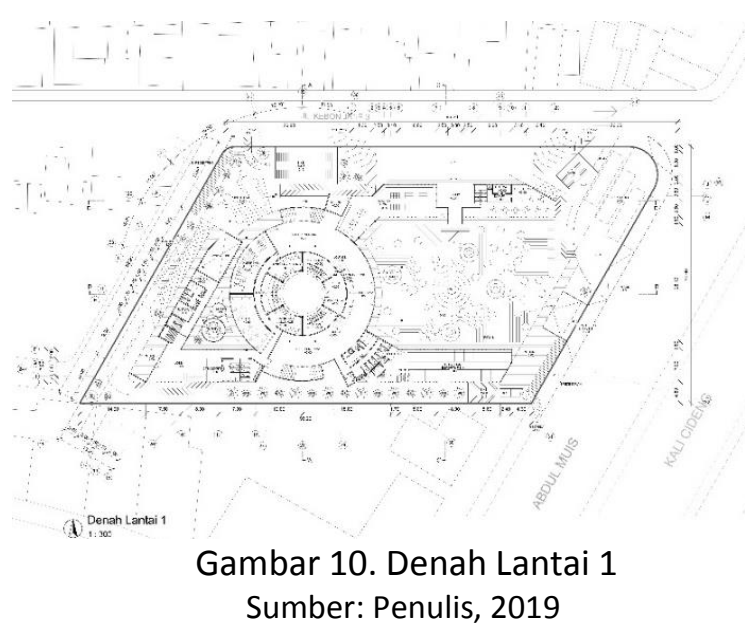

Denah Lantai 1 (Gambar 10) menjelaskan mengenai sirkulasi kendaraan maupun pedestrian. Simulasi ketika orang datang ialah melewati entrance, baik entrance transportasi umum, pedestrian maupun kendaraan pribadi, kemudian memasuki lobby, kemudian menuju ruang tengah (plaza), dan kemudian menyebar sesuai dengan kebutuhan, untuk menuju fasilitas pendukung bisa menuju ke arah utara maupun selatan, sedangkan menuju esports arena ke arah barat.
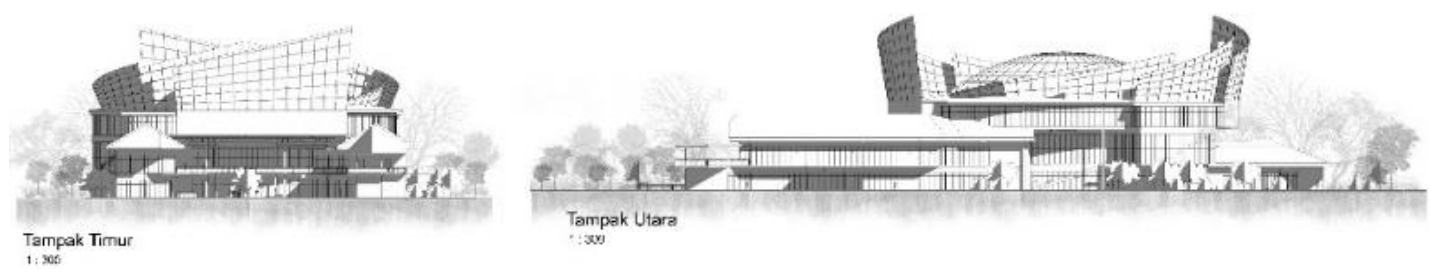

Gambar 11. Tampak

Sumber: Penulis, 2019

Tampak (Gambar 11) menunjukkan ukuran bangunan dan manusia (human scale), pada tampak bangunan utama terlihat jelas pada bagian timur dan utara, yang terdapat jalan utama. 


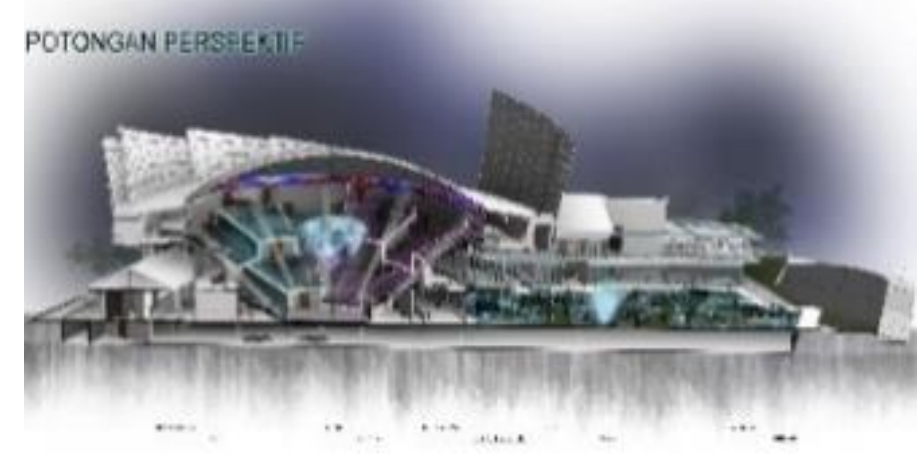

Gambar 12. Potongan Perspektif

Sumber: Penulis, 2019

Pada potongan perspektif (Gambar 12), plaza dan esports arena memegang peranan penting sebagai tempat berkumpul orang banyak. Plaza sebagai titik kumpul atau ruang tengah yang terlihat pada kanan gambar, dan esports arena pada kiri gambar, dibuat terdapat perbedaan peil untuk mengoptimalkan jumlah kursi dan menyesuaikan dengan kenyamanan penonton, seperti jarak pandang menuju layar.

Berikut gambar perspektif bangunan dari jalan utama, aerial view, plaza, esports arena, dan ruang latihan esports. (Gambar 13-Gambar 17)

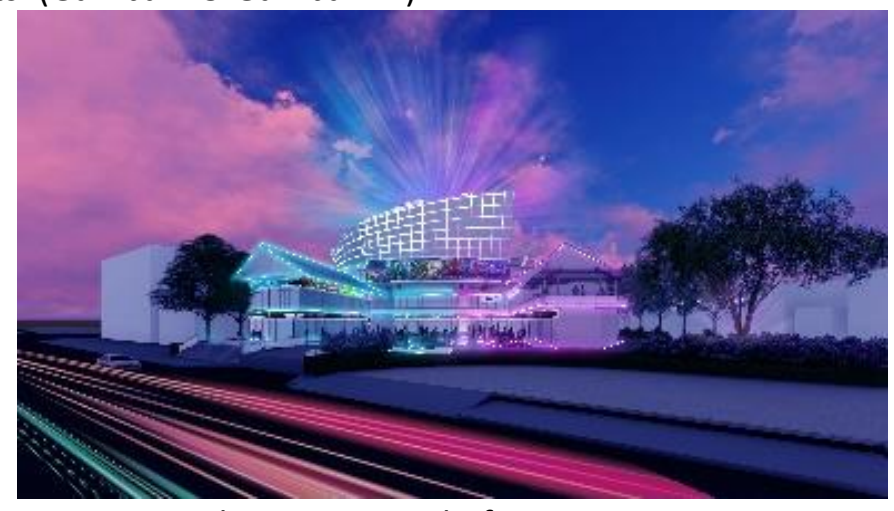

Gambar 13. Perspektif-Human eye view

Sumber: Penulis, 2019

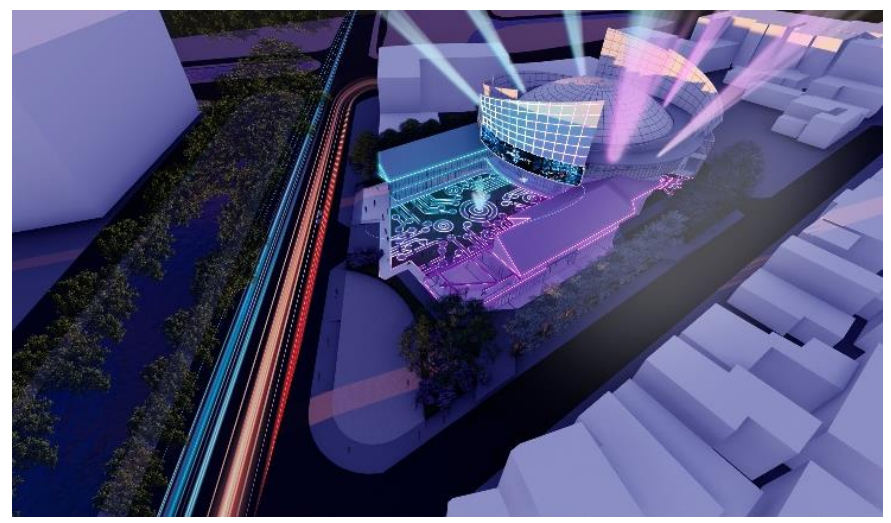

Gambar 14. Perspektif-Bird eye view

Sumber: Penulis, 2019 


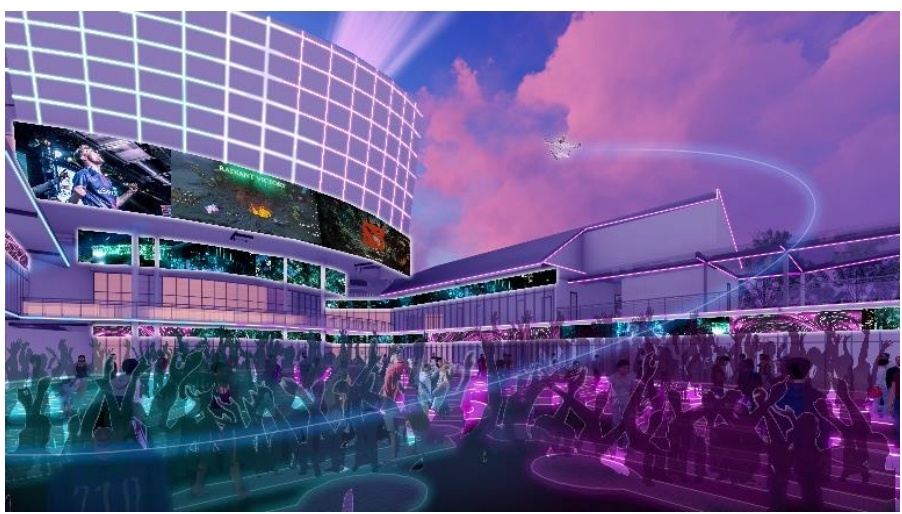

Gambar 15. Perspektif Eksterior (Plaza)

Sumber: Penulis, 2019

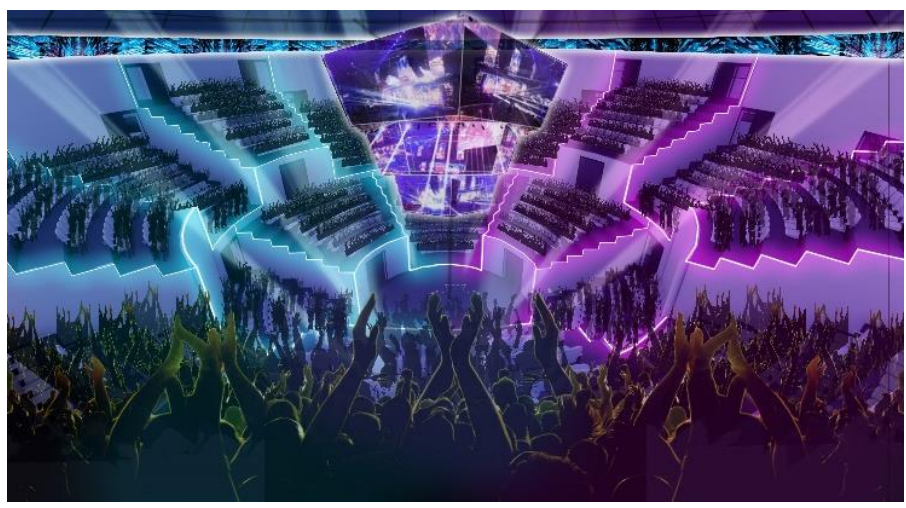

Gambar 16. Perspektif Interior (Esports Arena) Sumber: Penulis, 2019

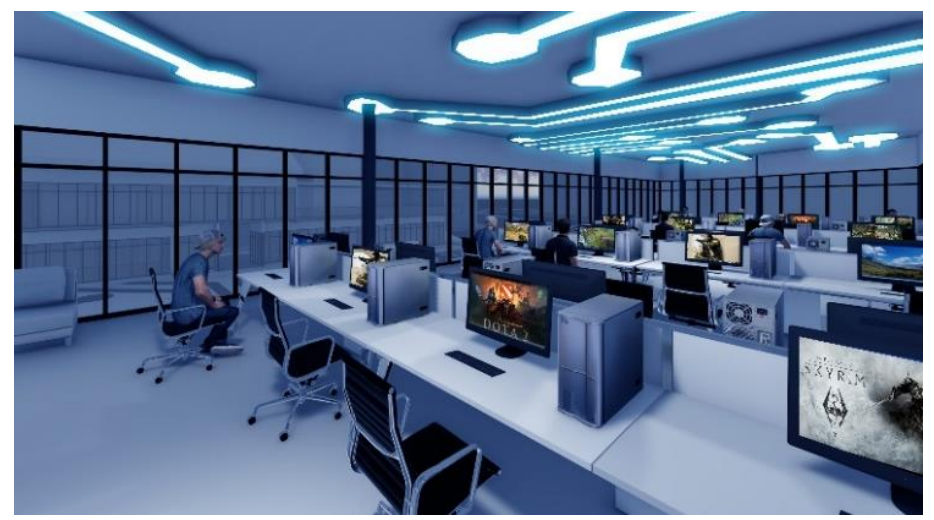

Gambar 17. Perspektif Interior (R. Latihan Esports) Sumber: Penulis, 2019

\section{KESIMPULAN DAN SARAN Kesimpulan}

Program yang menjawab hubungan keruangan antara tipe bangunan, perilaku dan kesejamanan milenial ialah program untuk kompetisi esports, program latihan esports, program plaza atau tempat titik berkumpul, dan program penunjang lainnya seperti cafeteria dan toko esports.

Perancangan dan konsep bentuk esports arena di lokasi tapak terpilih akibat pengaruh dari perilaku milenial dan tantangan dan kesejamanan milenial ialah berupa bentuk bangunan yang memusat, kontras, adanya plaza sebagai ruang tengah, adanya pengalaman ruang penuh teknologi dan menyesuaikan dengan tema terpilih yang sesuai dengan bangunan esports arena. 
Perancangan esports arena dapat menjadi jawaban untuk kebutuhannya yang belum terwadahi. Esports arena dapat menjadi wadah akan minat esports yang tinggi dan pemicu berlangsungnya efek domino untuk perkembangan lainnya. Esports arena menjadi tempat penyelenggaraan kompetisi esports dan program untuk esports secara khusus.

Berdasarkan analisis dan sintesis serta studi yang dilakukan, penulis menyimpulkan bahwa Esports Arena yang dirancang sesuai dengan tema "Dear Millennials, Dialogue Between Type and Behavior" karena merupakan bangunan khas milenial yang hadir dan menandai bahwa pernah ada generasi milenial pada zamannya. Selain itu, Esports Arena yang berlokasi di Petojo Selatan, Jakarta Pusat ini juga menjadi wadah untuk penyelenggaraan kompetisi yang difungsikan secara khusus untuk esports yang belum pernah ada sebelumnya.

\section{Saran}

Saran untuk perancangan esports arena selanjutnya, yaitu lebih memerhatikan dan mengaplikasian metode, tema, konsep bangunan secara keseluruhan pada bangunan dan lebih mengeksplorasi dan eksperimen bentuk gubahan massa, serta memperhatikan sistem utilitas lebih dalam. Selain itu juga dapat menggunakan pendekatan perancangan lain yang lebih khusus untuk esports arena.

\section{REFERENSI}

Alexander, C., dkk. (1977). A Pattern Language. New York: Oxford University Press.

Bull, S. (2018). "What to Consider When Designing an Esports Venue" dalam SEATI (hlm. 100102). Ohio.

Bramantya, B. (2011). tt. Universitas Diponegoro: Semarang.

Kamus Besar Bahasa Indonesia (KBBI). https://kbbi.web.id/nilai. Diakses 22 Januari 2019. . https://kbbi.web.id/perilaku. Diakses 22 Januari 2019. . https://kbbi.web.id/tipe. Diakses 22 Januari 2019.

Katadata. (2019). Jumlah Penduduk Indonesia 2019 Mencapai 267 Juta Jiwa. https://databoks.katadata.co.id/datapublish/2019/01/04/jumlah-penduduk-indonesia2019-mencapai-267-juta-jiwa. Diakses 1 Februari 2019.

Merlin, L. (2018). Every great sport has a cathedral: the future of the eSports experience. https://blooloop.com/features/esports-future-andy-miah-populous-video-game-arena/. Diakses 10 Februari 2019.

Merriam-Webster. (2019). https://www.merriam-webster.com/dictionary/building. Diakses 22 Januari 2019.

https://www.merriam-webster.com/dictionary/contemporaneity. Diakses 22 Januari 2019.

Newzoo. (2015). Newzoo Summer Series \#21: Indonesian Games Market. https://newzoo.com/insights/infographics/newzoo-summer-series-21-indonesian-gamesmarket/. Diakses 21 Januari 2019.

2017. The Indonesian Gamer. https://newzoo.com/insights/infographics/theindonesian-gamer-2017/\#. Diakses 22 Januari 2019.

Oxford Dictionaries. https://en.oxforddictionaries.com/definition/e-sport. Diakses 18 Januari 2019.

Panindya, B. (2018). Menjadi Generasi Millennial yang Selalu Kreatif, Aktif, dan Inovatif. https://www.kompasiana.com/belfast/5a598c1dbde5754d8c498382/menjadi-generasimillennial-yang-selalu-kreatif-aktif-dan-inovatif\#. Diakses 21 Januari 2019.

Sachs, G. (2018). There's No Stopping Esports. https://www.goldmansachs.com/insights/pages/infographics/e-sports/. Diakses 12 Februari 2019.

Setiawan, R. (2017). Seberapa Besar Industri Game Indonesia?. 
https://rickysetiawan.com/2017/03/18/seberapa-besar-industri-game-indonesia/. Diakses 21 Januari 2019.

Walidah, I. A. (2017). "Tabayyun di Era Generasi Millennial" dalam Jurnal Living Hadis Vol. 2 No. 1 (hlm. 317-344). Yogyakarta: Fakultas Ushuluddin dan Pemikiran Islam UIN Sunan Kalijaga Yogyakarta. 
